\title{
ODPOWIEDŹ NA RECENZJĘ KRZYSZTOFA MULARSKIEGO
}

Jarosław Kuisz

Odpowiedź na recenzję nastręcza trudności, gdyż recenzent odstępuje od standardów pracy naukowej i traktuje ją jako pretekst do swobodnych wypowiedzi na inne tematy. Ponadto, nie zawsze przedstawiając argumenty na rzecz swoich ocen ${ }^{1}$, nie rezygnuje z krytyki wyrażanej pryncypialnym tonem. Autor przy tym wypowiada en passant opinie naukowo „samobójcze": o kryteriach personalnych, które powinien spełniać naukowiec, by w ogóle przystapić do wypowiadania swoich ocen czy też o podejmowaniu się prac nad zagadnieniami, których rezultat może pozostawać przedmiotem dalszych dyskusji.

Po tych uwagach wstępnych odnieśmy się jednak do istotnych problemów związanych z książką, na które recenzent zwrócił uwagę i o których niewątpliwie warto porozmawiać przy okazji naukowej recenzji: (1) problem doboru literatury; (2) problem tematu książki; (3) problem pozytywizmu prawniczego w Polsce Ludowej; (4) problem poszukiwania wydarzeń analogicznych do opisywanych w pracy naukowej.

\section{/// Problem literatury}

Pierwsza istotna uwaga dotyczyła bazy źródłowej. Zaznaczmy, iż rzeczywiście normalnym zjawiskiem jest, że historycy zajmujący się dziejami Polski Ludowej trudzą się nad ogromem materiału źródłowego. Konieczność selekcji jest po prostu norma (zresztą nie tylko w tej, ale w ogóle w każdej dziedzinie współczesnej humanistyki). Można się natomiast spierać o sposób odsiania ziaren od plew.

Spójrzmy zatem, co autor recenzji zaproponował, pisząc o „całym szeregu artykułów nieuwzględnionych w pracy”, które ukazały się w czasopiśmie „Nowe Prawo” od numeru 3 do numeru 9 z 1981 r. Niezorientowany czytelnik może oczekiwać, iż ominięto wiele znakomitych i ważnych publikacji. Nic bardziej błędnego. Oto autor recenzji mógł na poważnie

\footnotetext{
${ }^{1}$ Np. dla krytyki części syntetycznej pracy czy też dla wyboru danej publikacji z dzieł H. Kelsena celem lepszego wyjaśnienia zagadnienia rewolucja a prawo - o czym dalej.
} 
mieć na myśli jedynie trzy teksty, które jako żywo do rozważań, będących przedmiotem książki, nie wnoszą nic nowego. Poza wspomnianym przez autora tekstem Bohdana Zdziennickiego mamy tekst Józefa Szczerskiego Waizniejsze problemy nowelizacï kodeksu pracy („Nowe Prawo” nr 7-8 z 1981 r.), którego autor co prawda wspomina o realizacji postulatów zawartych w dokumentach porozumień z Gdańska, Szczecina i Jastrzębia, ale w niczym nie wykracza poza inne tego typu teksty na temat postulowanych zmian w prawie pracy, które obficie są cytowane w książce ${ }^{2}$ i obejmują cały okres posierpniowy.

Co do tekstu Zdziennickiego, to poglądy tego autora znacznie lepiej odzwierciedla - uwzględniony w książce - tekst $O$ należna range prawa, który ukazał się w „Gazecie Prawniczej” już we wrześniu 1980 r. Publikacja o tyle ciekawsza, że była jedna z pierwszych prób odniesienia się do aktualnych wydarzeń na łamach prasy przez prawnika.

$\mathrm{Na}$ łamach „Nowego Prawa” pojawia się jeszcze relacja Elżbiety Sobótki Kierunki reformy prawa pracy (Sesja Komitetu Nauk Prawnych Polskiej Akademii Nauk Warsqawa 1981) („Nowe Prawo” nr 9 z 1981 r.). Jednak wspominam o tekście z ostrożności, zakładam, że autor recenzji raczej nie mógł go mieć na myśli (?). Autorka - posługując się bardzo mocnym filtrem - jedynie ogólnie zreferowała w nim wystąienia uczestników z sesji Komitetu Nauk Prawnych Polskiej Akademii Nauk. W efekcie tych zabiegów w ostrożnej w tonie relacji pojawiają się dobrze znane stwierdzenia o tym, że np.: „podkreślano, że jeden z zasadniczych kierunków zmian został wyznaczony przez porozumienia zawarte w Gdańsku, Szczecinie i Jastrzębiu. Nowelizacja kodeksu pracy powinna wprowadzić zmiany będące konsekwencją podpisania tych dokumentów". Znów wypada powtórzyć, iż takich stwierdzeń w książce czytelnik znajdzie pod dostatkiem.

Warto więc podkreślić, że - podobnie jak w przypadku tekstu Zdziennickiego - Sobótka popełniła artykuł o wiele ciekawszy, uwzględniony przeze mnie w książce, a mianowicie: E. Sobótka, Porozumienia społeczne w systemie prawa pracy (Sobótka 1983). Autorka usiłowała w nim, szerzej niż sugerowałby to tylko tytuł, teoretycznie ująć funkcjonowanie porozumień sierpniowych w systemie prawno-politycznym Polski Ludowej.

Dodajmy wreszcie, że autor recenzji, czyniąc zarzut z nieuwzględnienia tekstów, o których mowa w „Nowym Prawie”, trafnie zauważa, że jest to źródło pomniejszej wagi. Nie przeszkadza to mu jednak w posłużeniu się nim jako argumentem.

\footnotetext{
${ }^{2}$ Dość wspomnieć o serii tekstów dla „Państwa i Prawa” takich autorów, jak: W. Szubert, J. Jończyk $\mathrm{i}$ in. czy o dyskusjach na temat nowelizacji kodeksu pracy, które toczyły się na łamach „Gazety Prawniczej” i „Prawa i Życia”.
} 
Recenzent nie dostrzega natomiast dodatkowego kryterium selekcji materiału: oto - pozostawiając już kwestię kryterium oceny „specjalistyczności” czy „popularności” danego czasopisma ${ }^{3}$ - teksty z „Nowego Prawa” w ogóle (!) nie były cytowane w literaturze, która dotyczyła wybranej do analizy materii badawczej. Krótko mówiąc, nie podejmowano z nimi tak gorącej dyskusji, jaką np. zainicjował tekst Leszka Garlickiego na łamach „Państwa i Prawa”, opublikowany w numerze ze stycznia 1981 r.

\section{/// Problem tematu książki}

Rozprawa na pewno ma swoje ograniczenia, jednak autor recenzji przypisuje jej inne cele badawcze niż te, o których informuje „Wstęp”. Recenzent nieprawidłowo stwierdza, że zamierzeniem autora książki: „,było przedstawienie materiału empirycznego dla uzasadnienia głoszonej tezy o możliwości istnienia negocjacyjnej formy stanowienia prawa w ustroju niedemokratycznym".

To tylko jeden z wniosków wynikających z pracy, która miała jednak rozleglejsze założenia. Cieszyć się wypada, że akurat ten wniosek wzbudził zainteresowanie recenzenta, ale niestety, recenzja nie daje pojęcia o tym, czemu poświęcona jest książka.

Powtórzmy zatem - jej celem było całościowe przypomnienie zapomnianego dziś sporu o porozumienia sierpniowe w okresie od sierpnia 1980 do grudnia 1981 r. Miał on bowiem swoje różne odsłony, w tym na polu nauk prawnych. Spierano się między innymi o to, czy i w jakim zakresie porozumienia obowiązują, jak się mają do obowiązujących przepisów, w jakim stopniu powinny one uwzględniać sądy powszechne etc. Usiłowano wreszcie przełożyć treść porozumień sierpniowych - właśnie tych dokumentów, które z takim mozołem wynegocjowano w zakładach pracy - na język aktów prawnych. Wszystko to miało więc swoje jak najbardziej praktyczne znaczenie.

Wstęp do książki uprzedzał, iż przez próbę określenia „charakteru prawnego porozumień sierpniowych" - czyli porozumień zawartych w dniu 30 sierpnia 1980 r. w Szczecinie, 31 sierpnia 1980 r. w Gdańsku oraz 3 września 1980 r. w Jastrzębiu - rozumiemy przede wszystkim analizę porozumień pod kątem ich umiejscowienia w systemie prawa PRL. Próby umiejscowienia porozumień sierpniowych w tych ramach - jakkolwiek

\footnotetext{
${ }^{3} \mathrm{Na}$ marginesie przyznać muszę, iż nie rozumiem, co recenzent ma na myśli, pisząc, iż „Nowe Prawo” było czasopismem „nie tak specjalistycznym” jak „Państwo i Prawo”. Czy chodzi o nakład? We wspomnianym okresie - tj. od numeru 3 do numeru 9 z 1981 roku - nakład czasopisma oficjalnie wynosił 8110 egzemplarzy. W przeciwieństwie do „Państwa i Prawa” (nakład w grudniu 1980 roku wynosił 11600 egzemplarzy, zaś w pierwszych miesiącach 1981 roku uległ nieznacznemu zmniejszeniu do ok. 10280 egzemplarzy).
} 
karkołomnie by to z pozoru brzmiało - mają swoją fascynującą historię, której poświęciłem całą moją książkę.

Mój polemista nie przeczytał jej, niestety, uważnie. Dlaczego tak sądzę?

Przede wszystkim chodzi o zarzut wobec stwierdzenia, iz porozumienia sierpniowe to akt o charakterze sui generis, mający znaczenie polityczno-prawne. Podtrzymuję w tej kwestii swoja ocenę. W obrębie istniejącej terminologii nie ma lepszego, a sformułowanie sui generis w naukach prawnych nie jest niczym nadzwyczajnym. Brak odpowiedzi - satysfakcjonującej dla samego recenzenta - nie powinien zresztą umniejszać wagi prób odpowiedzi na zadane pytanie. W książce jednak zostało podkreślone w „Zakończeniu”, iż charakter prawny porozumień sierpniowych pozostaje niejednoznaczny i uzależniony od przyjętej perspektywy teoretycznej.

Gdybyśmy mieli ów charakter określić - w ujęciu syntetycznym (porozumienia ujmowane jako całość) - najmniej dyskusyjne wydaje się określenie, że porozumienia sierpniowe to akt o charakterze sui generis, mający znaczenie polityczno-prawne ${ }^{4}$.W ujęciu analitycznym natomiast, tj. w odniesieniu do wybranych ustaleń, stosunkowo najmniej wątpliwości dla teorii prawa nastręcza określanie porozumień jako aktów co najmniej inspirujących inicjatywę ustawodawczą ${ }^{5}$.

Jak sądzę, o porozumienia sierpniowe można i należy się spierać właśnie dlatego, że nie poddają się łatwej klasyfikacji. Porozumienia sierpniowe mogą być wydarzeniem, na którym można sprawdzać założenie różnych nie tylko pozytywizmu prawniczego - teorii i filozofii prawa. Nie zgadzam się z założeniem, które recenzent mimowolnie przyjmuje, iż najlepiej pytać o to, na co z góry można odpowiedzieć.

Ponadto niepokoi i zaskakuje pytanie recenzenta: ,po co warto pamiętać o sile społecznych postulatów?”. Postulaty były punktem wyjścia do podpisanych porozumień sierpniowych. Jak wykazałem, niektóre z nich, zgłaszane już w 1970 r., powróciły w 1980 r. Metaforyczną „siłę”, moim zdaniem, oddaje to, iż de facto część postulatów zgłoszonych w Sierpniu'80 - w świetle późniejszych wydarzeń - należy potraktować jako nieformalna inicjatywę legislacyjną. W sytuacji, w której część postulatów stała się przed 13 grudnia 1981 r. obowiązującym prawem, mówienie o „sile postulatów" nie jest chyba przesada. W końcu 31 sierpnia - rocznica podpisania Porozumień Gdańskich - stał się jako „Dzień Solidarności i Wolności”

\footnotetext{
${ }^{4}$ Należy z żalem zauważyć, że recenzent, zajmując krytyczne stanowisko wobec podejścia syntetycznego, nie przedstawia racji, dla których je przyjął.

${ }^{5}$ Jednak chodzi tu o coś więcej, niż zgłaszanie postulatów de lege ferenda. Zobowiązano w formie pisemnej rząd PRL do podjęcia konkretnych inicjatyw ustawodawczych, wedle określonych zasad. Następnie po stronie związkowej skrupulatnie kontrolowano, na ile te prace postępują i pozostają w zgodzie z porozumieniami sierpniowymi, a także występowano z inicjatywami własnymi.
} 
świętem państwowym, ustanowionym przez Sejm Rzeczypospolitej Polskiej ustawą z 27 lipca 2005 r. ${ }^{6}$ Jeśli jednak idzie tylko o to, iż autor recenzji preferuje w publikacjach język skrajnie suchy, to p o g o d z e n i e m stanowisk byłaby klasyczna formuła: De gustibus non disputandum est.

\section{/// Problem poszukiwania analogii}

Jeśli chodzi o propozycje umiejscowienia porozumień sierpniowych w szerszym kontekście, to - jako wykraczające poza temat określony tytułem - zostały one przeze mnie celowo pozostawione poza rozprawa. Próby zlokalizowania porozumień sierpniowych w kontekście wcześniejszych wydarzeń z historii Polski badałem już zresztą na przykładzie Porozumienia Gdańskiego (Kuisz 2008b). Trudności z zakwalifikowaniem porozumień sierpniowych są lustrzanym odbiciem trudności, jakie mają teoretycy z zakwalifikowaniem NSZZ ,Solidarność” w okresie 1980-1981.

Szkoda, że - skoro już recenzent podjął ten wątek - nie pokusił się o sprawdzenie stanu publikacji na ten temat. Propozycji jest sporo, więc jedynie tytułem przykładu podpowiedzmy, iż w związku z koncepcja porównania pierwszej „Solidarności” do „ruchu egzekucyjnego” recenzent mógłby zwrócić uwagę na tekst Jerzego Stępnia, „Solidarnośc”: ostatnia konfederacja? Korzystne mogłoby być także uwzględnienie usystematyzowanych rozważań pióra Marka Latoszka7. Zaproponował on - w obliczu trudności z zakwalifikowaniem pierwszej odsłony „Solidarności” - koncepcję podejścia integralnego, uwzględniającego walory poznawcze: ruchu społecznego, rewolucji oraz powstania - na zasadzie komplementarności. Jak się wydaje, same poszukiwania takich analogii mogłyby być już dziś przedmiotem osobnych badań.

Porównanie pierwszej „Solidarności” do ruchu egzekucyjnego jest kontrowersyjne, już choćby z tego powodu, iż nie można - bez poczynienia istotnych zastrzeżeń, których recenzent nie poczynił - porównać sytuacji I Rzeczypospolitej w XVI w. z sytuacją zależnej od ZSRR Polski Ludowej. Jednak zauważmy, iż w przedstawianiu takich propozycji recenzent nie pozostaje odosobniony i na szczęście nie są one aż tak kontrowersyjne, jakby się mogło na pierwszy rzut oka wydawać.

Przydatne moga tutaj okazać się ustalenia wynikające z tak zwanego „sporu o PRL”, w którym uczestniczyli historycy. Był on także sporem o to, jak zakwalifikować polską państwowość w okresie 1945-1989. Padały różne

\footnotetext{
${ }^{6}$ „Dz. U.” z 2005, Nr 155, poz. 1295.

${ }^{7}$ Latoszek (2005), także posługując się nieszczęsnym terminem „natura”, stwierdza na zakończenie: „Gdyby przyszło rozstrzygnąć o naturze „Solidarności” pozostają niedopowiedzenia, jako że jest ona ze względu na różne aspekty i wymiary zarówno: ruchem społecznym, rewolucją jak też sprawcą narodowego powstania".
} 
propozycje, na przykład Andrzej Friszke pisał: „Jeśli szukać w przeszłości podobnej formy państwa polskiego, to nasuwa się porównanie z Królestwem Kongresowym lat 1815-1830" (Friszke 1996: 111). W obu przypadkach, jak zauważył dalej znakomity historyk, „istniały pozory suwerenności i rzeczywista rozległa autonomia, rządziła polska administracja, działały polskie szkoły, uniwersytety, sądy, rozwijała się kultura. Autonomia była jednak ograniczona przez obowiązek całkowitej lojalności wobec Moskwy" (Friszke 1996: 111).

Warto tylko przypomnieć, że takie porównania wcale nie były i nie sa neutralne. Jak pisał Bronisław Baczko o Polsce Ludowej - państwo uważało bowiem, że do jego podstawowych kompetencji należy wyłączne kierowanie pamięcią społeczną, zaś władza komunistyczna od swego początku „stała przed nierozwiązywalnym [...] zadaniem: jak nadać sobie prawomocność historyczna" (Baczko 1994: 202-203). Podobnie zwolennicy NSZZ „Solidarność” - poprzez efektowne analogie m.in. dotyczące porozumień sierpniowych - także tej „prawomocności historycznej” szukali. Bez wątpienia przedmiotem kontrowersji pozostaje wciąż problem, czy zestawianie instytucji lub wydarzeń z I RP z instytucjami lub wydarzeniami z PRL jest bardziej efektownym chwytem publicystycznym niż rzetelną propozycją naukowa. Tu jednak odsyłam do przywoływanej wyżej publikacji, w której rozważałem m.in. wady i zalety powracającego w literaturze, porównania porozumień sierpniowych do paktów konwentów.

\section{/// Problem pozytywizmu prawniczego w Polsce Ludowej}

Największy mój sprzeciw budzi jednak stwierdzenie recenzenta, że „fakty opisywane przez pracę stanowią wielką pochwałę pozytywizmu prawniczego". Z uwag recenzenta wynika, że ma on na myśli tę wersję pozytywizmu, którą nazywa się pozytywizmem „twardym”. Za klasycznych przedstawicieli tej wersji uchodza John Austin oraz, analizowany przez autora recenzji, Hans Kelsen. Recenzent zatem pomija poglądy przedstawicieli pozytywizmu „miękkiego”, tj.: Herberta L.A. Harta, Josepha Raza, Neila MacCormicka oraz Oty Weinbergera.

Wyjaśnijmy, iżna pozytywizm prawniczy - w różnych odsłonach - składaja się co najmniej dwie tezy, a mianowicie „teza społeczna” i „teza o rozdziale”. Pierwsza z nich głosi, iż prawo to normy ustanowione lub uznane przez kompetentny autorytet normodawczy, zgodnie z przewidziana procedurą. Zgodnie $z$ drugą zaś, prawo i moralność to różne systemy normatywne, a obowiązywanie norm prawnych nie zależy od ich zgodności z normami moralnymi. „W szczególności, żadna norma prawna nie może utracić mocy obowiązującej z tego powodu, że jest niesłuszna lub niesprawiedliwa” (Morawski 2003). 
W wielu wypadkach tezę społeczną po stronie NSZZ „Solidarność” podtrzymywano ze względów taktycznych. W żadnym wypadku jednak nie można stwierdzić, że NSZZ „Solidarność” w okresie 1980-1981 przyjmowała, fundamentalną dla pozytywizmu prawniczego, tezę o rozdziale prawa i moralności!

Dla recenzenta, jak się wydaje, pozytywizm prawny sprowadza się do postulatu przestrzegania obowiązującego prawa. A przecież był to tylko jeden ze zgłaszanych postulatów i - co zupełnie zasadnicze - należący do tych postulatów, które można było ówcześnie otwarcie zgłosić. Liczne postulaty zwyczajnie nie mieściły się, jak chce recenzent, w ramach „egzekwowania obowiązujących przepisów”, inne postulaty odkładano „na później”, inne wreszcie przedstawiano w takiej formie, by mogły zostać zaakceptowane przez władze. Taktykę zgłaszania postulatów przez NSZZ „Solidarność" opisałem szerzej w przeoczonym przez recenzenta artykule, premierowym w stosunku do książki (Kuisz 2008a).

Co ważne, żądania przedstawiane w imieniu NSZZ „Solidarność”, by szanowano obowiązujące przepisy, nie prowadzą automatycznie do akceptowania filozofii pozytywizmu prawniczego. Recenzent rozpięty jedynie pomiędzy pozytywizmem prawniczym a prawem natury nie uwzględnił innych doktryn polityczno-prawnych. Na jego usprawiedliwienie dodajmy, iż błąd ten już wcześniej popełniano (Wrzesiński 1992: 213-215).

Owszem, obie strony konfliktu starały się wykazać, że działają zgodnie z obowiązującymi przepisami prawa, ale to przecież nie oznaczało, że bez zastrzeżeń akceptowano istniejący system prawa Polski Ludowej i wszystkie obowiązujące przepisy. Sytuacja była niezwykle skomplikowana, bo o b o wiązujące przepisy naruszały obie strony. Na wszelki wypadek wielu teoretyków udawało, iż... nic się nie stało.

Oto już samo skorzystanie przez robotników z prawa do strajku latem 1980 r. było tego porządku jawnym naruszeniem. Zamieszanie w związku z podpisaniem porozumień było tak wielkie, że uchwała Rady Państwa z dnia 13 września 1980 r., regulująca zasady rejestracji nowo powstałych związków zawodowych, została podjęta jeszcze przed uchwaleniem przez Sejm PRL ustawy, która Radę Państwa do tego upoważni (sic!). Przykłady można mnożyć.

$\mathrm{Na}$ tle rozważań o porozumieniach sierpniowych widać co chwila tzw. kwestie polityczne, które przeważyły nad literą obowiązującego w PRL prawa. W związku z tym wszystkim warto odesłać do książki. Należy również zalecić większe wyczulenie na realia okresu szesnastu miesięcy „Solidarności”, by nie lekceważyć, jak to się dzieje w omawianej przeze mnie recenzji, opisanej przecież w książce taktyki działania NSZZ „Solidarność" w ramach istniejącego porządku prawnego. 
Warto dodać, iż pozytywizm prawny wymaga stosownego otoczenia kulturowego, którego w Polsce Ludowej próżno szukać. Grażyna Skąpska wręcz stwierdziła, że w Polsce Ludowej należy mówić nie o kulturze prawnej, a raczej o kulturze antyprawnej. Wymieniła też następujące jej cechy: „niepohamowany instrumentalizm, polityzacja i ideologizacja prawa, jego publicyzacja, chaos semantyczny i ogólnie lekceważący stosunek do prawa, traktowanego jako «narzędzie przemian» stosowanego wtedy, gdy było to wygodne, oraz [...] «hipokryzja»" (Skapska 1998: 285 i n.).

Recenzent wspomina o ustawach norymberskich i to może nas naprowadzić na źródło jego osobliwej propozycji. Warto pamiętać, iż rozważania na temat tego, czy w III Rzeszy pozytywizm prawny był dominująca doktryną wśród niemieckich prawników, od dawna prowadzone są w sposób niezwykle zniuansowany. Dobrze oddał to Jerzy Zajadło w książce Formuła Radbrucha, pisząc: „można wiele zarzucać pozytywizmowi prawniczemu, ale na pewno nie to, że był doktryna panująca w niemieckiej nauce i praktyce prawa w latach 1933-1945" (Zajadło 2001: 295).

To samo dałoby się mutatis mutandis powiedzieć o Polsce Ludowej. Nieostrożne byłoby więc przypisywanie NSZZ „Solidarność” wyłącznie filozofii pozytywizmu prawniczego. Sami prawnicy związani z NSZZ „Solidarność" nie mówili na ten temat jednym głosem. Jeszcze raz trzeba podkreślić, iż nie można twierdzić, że związkowcom, którzy zgłaszali postulaty, relacja między prawem a moralnością była obojętna. W książce opisany został przecież - także bezpośrednio związany z porozumieniami sierpniowymi - kryzys rejestracyjny. Na przykładzie opisanego w książce procedowania Sądu Wojewódzkiego w Warszawie (24 października 1980 r.) widać, że problemem była sama niezawisłość sędziowska i zakulisowe rozgrywki.

Nieostrożne jest więc przypisywanie pozytywizmu czy neopozytywizmu prawniczego sędziom sądów w Polsce Ludowej ${ }^{8}$. Trafniej byłoby powiedzieć, że ślepe podporządkowanie władzy zajęło miejsce pozytywistycznego związania sędziego ustawa. Zapewne można mówić o socjopsychologicznej podatności części polskich prawników na podporządkowanie się autorytarnej władzy (por. Zajadło 2001: 294). W odniesieniu do polskich prawników należy jednak powtórzyć, to co powiedziano o prawnikach

\footnotetext{
${ }^{8}$ A. Strzembosz i M. Stanowska napisali, że: ,przez całe lata sześćdziesiąte, siedemdziesiąte i osiemdziesiąte w polskiej nauce królowała doktryna neopozytywizmu prawniczego, która zastępując prymitywną teorię prawa jako narzędzia walki klas, legitymizowała jednak każde prawo w prawidłowy sposób uchwalone i ogłoszone. Teoria ta odegrała niechlubną rolę w okresie będącym przedmiotem naszych szczegółowych rozważań, gdyż była usprawiedliwieniem dla tych sędziów, którzy z tchórzostwa lub oportunizmu z całą bezwzględnością stosowali regulacje stanu wojennego. Jeszcze dzisiaj na zarzut wydawania surowych wyroków za działalność powszechnie uznaną nie tylko za dopuszczalną, ale za służącą dobru wspólnemu odpowiadają, że stosowali prawo” (Strzembosz, Stanowska 2005: 293).
} 
niemieckich: ,Jest to jednak problem, który wymyka się wprawdzie kryteriom naukowej oceny, ale nie powinno to oznaczać rezygnacji z racjonalnego dyskursu nad różnymi jego aspektami” (Zajadło 2001: 295).

Wyjaśnijmy jeszcze, iż w książce pozytywizm prawny Hansa Kelsena niezbędny był jako przykład „ekstremalnej” propozycji teoretycznej, pozwalającej na uporządkowanie zgromadzonego materiału. Nie było moim zamiarem ani krytykowanie, ani chwalenie pozytywizmu prawniczego w jakiejkolwiek postaci. Zamiast sięgać po prostu do Caystej teorii prawa dla pracy merytorycznie właściwsze było sięgniecie do późniejszej książki austriackiego teoretyka, którą recenzent znów, bez jakichkolwiek poważnych wyjaśnień, dyskwalifikuje po prostu jako „mętną". Zdumiewające, albowiem język późnych prac Kelsena należy wręcz zalecać jako wzór przejrzystości i jasności wywodu.

\section{/// Zakończenie}

W pracy zastanawiałem się nad charakterem prawnym porozumień sierpniowych. Pod sformułowaniem „o poszukiwaniu istoty” czy „,natury”, które w naukach prawnych (i nie tylko w naukach prawnych) nie jest niczym nadzwyczajnym, ba, jest jedynie pewną konwencją kryje się banalne pytanie o to, w jaki sposób z perspektywy nauk prawnych można było zakwalifikować porozumienia sierpniowe, które doprowadziły m.in. do konkretnych zmian w obowiązujących przepisach. Sięganie aż do Arystotelesa - może i wartościowe dla efektu retorycznego - tu jest zgoła niepotrzebne, albowiem wystarczy zauważyć, że sam autor recenzji ma tej konwencji pełną świadomość. Oczywiście, każdą próbę wzbogacenia języka czy wyrażenia swojej opinii w mniej kategoryczny sposób można próbować podważyć. Jednakże, czytając nawet tekst sensu stricto akademicki, warto też pamiętać o Czytelniku. Nie chodzi o uatrakcyjnianie na siłę, ale też nie chodzi o utrudzenie lekturą. Autor recenzji w tym punkcie być może nadmiernie zwątpił w siły Czytelnika, sięgającego po książkę o charakterze naukowym. Niesłusznie, jak sądzę. Nie trzeba ab ovo tłumaczyć każdego sformułowania.

Ocenę pozostałych przedstawionych w recenzji zarzutów pozostawiam Czytelnikom. Jak sądzę, można dokonać ich bez lektury książki. Autorowi recenzji pozostaję zaś niezmiernie wdzięczny za wszystkie krytyczne uwagi. Pozostając w niezgodzie co do ich zasadności, mam jednak nadzieję, że wspólnie przyczynimy się do zainteresowania poruszoną w tekstach problematyka. 
Bibliografia:

/// Baczko, B. 1994. Polska czasów „Solidarności”, cazyli eksplozja pamieci. W: Tenże, Wyobrażenia spoteczne. Warszawa: PWN, s. 202-203.

/// Friszke, A. 1996. Państwo polskie - autonomiczna cześś imperium. W: Spór o PRL. Kraków: Znak, s. 111.

/// Kuisz, J. 2008a. O pojmowaniu praworzadności w Polskiej Rzecsypospolitej Ludowejw latach 1980-1981. W zwiazku zpraca Adama Lityńskiego. „Czasopismo Prawno-Historyczne" 2/2008.

/// Kuisz, J. 2008b. Porozumienie Gdańskie w polskiej tradycji ustrojowej (zarys problemu). „Studia Iuridica” 48 (2008).

/// Latoszek, M. 2005. „Solidarnosí”: ruch społeczny, rewolucja cayy powstanie?. W: „Solidarność” w imieniu narodu i obywateli. Latoszek M. (red.). Kraków: Arcana, s. $240 \mathrm{i} \mathrm{n.}$

/// Morawski, L. 2003. Pozytywizm „twardy”, pozytywizm ,miekki” i pozytywizm martwy. „Ius et Lex” 1/2003.

/// Skapska, G. 1998. Źródta kultury antylegalizmu. W: Teoria prawa. Filozofia prawa. Wspótczesne prawo i prawoznawstwo. Toruń: Wydawnictwo UMK.

/// Sobótka, E. 1983. Porozumienia społeczne w systemie prawa pracy. W: Florek L., Gienieczko E. i Sobótka E. Z problematyki rokowań i porozumień zbiorowych pracy, Studia i Materialy IPiSS (zeszyt 7). Warszawa.

/// Stępnień, J. 2008 „Solidarnośc”: ostatnia konfederacja? W: Lex est Rex in Polonia et in Lithuania... Tradycje prawno-ustrojowe Rzecsypospolitej - doświadcæenie i dziedzictwo. Warszawa: DiG.

/// Strzembosz, A. i Stanowska, M. 2005. Sedziowie warszanuscy w czasie próby 1981-1988. Warszawa: IPN, s. 293.

/// Wrzesiński, K. 1992. Pozytywizm prawny w Polsce Ludowej: præestanki teoretyczne a konsekwencje praktyczne. W: Czech B. (red.). Filozofia prawa a tworzenie $i$ stosowanie prawa. Katowice, s. 213-215.

/// Zajadło, J. 2001. Formuła Radbrucha. Filozofia prawa na granicy posytymizmu prawniczego i prawa natury. Gdańsk: Arche. 